\title{
The clinical significance of the anti-RA33 level in patients with rheumatoid arthritis
}

\section{Romatoid artritli hastalarda Anti-Ra 33 seviyesinin klinik önemi}

\author{
Mehmet Türkmen ${ }^{1}$, Emrullah Hayta ${ }^{2}$, Hasan Elden², Ahmet Karadağ²
}

${ }^{1}$ Clinics of Physical Medicine and Rehabilitation, Samsun Physical Medicine and Rehabilitation Hospital, Samsun,Turkey ${ }^{2}$ Department of Physical Medicine and Rehabilitation, Cumhuriyet University Faculty of Medicine, 58140 Sivas, Turkey Corresponding author: Dr. Emrullah Hayta, Department of Physical Medicine and Rehabilitation, Cumhuriyet University Faculty of Medicine, 58140 Sivas, Turkey

E-mail: dremay@gmail.com

Received/Accepted: September 15, 2015 / August 17, 2016

Conflict of interest: There is not a conflict of interest.

\section{SUMMARY}

Objective: The early diagnosis of Rheumatoid Arthritis (RA) is of due significance for the prevention of possible damage to the joint tissue by means of treatment. Laboratory tests are very important for monitoring RA activity and for the evaluation of the patients' response to the treatment. Rheumatoid factor, so far the most commonly used test for the cases with suspected RA, is not a specific parameter despite its sensitivity to RA. The measurement of other autoantibodies might be helpful to the diagnosis particularly for the cases with low RF titer or with suspected diagnosis. The measurement of anti-RA33 autoantibodies is one of the tests used in the diagnosis of the RA cases. The present study was conducted to compare anti-RA33 levels of healthy individuals with long-term RA cases and to evaluate the value of anti-RA33 test for the RA diagnosis.

Method: Total 40 patients ( 28 female and 12 male) identified with RA at least for the last five years according to the classification criteria of American College of Rheumatology (ACR) reviewed in 1987 and 40 healthy controls included in the present study.

Results: AntiRA-33 level was determined as $12.47 \pm 4.97 \mathrm{U} / \mathrm{mL}$ for the patients with RA and as $1.96 \pm 1.82 \mathrm{U} / \mathrm{mL}$ for the healthy controls, and there is no statistically significant difference between the groups.

Conclusions: As a result AntiRA-33 level was evaluated in RA patients and no difference was found compared to control group.

Keywords: Rheumatoid Arthritis, Rheumatoid Factor, Anti-RA33

\section{ÖZET}

Amaç: RA tanısının erken konulması, tedavi ile eklem dokusundaki hasarın önüne geçilebilmesi açısından çok önemlidir. Laboratuar testleri, RA aktivitesinin izlenmesinde ve tedaviye yanıtın değerlendirilmesinde oldukça önemlidir. RA şüphesi olan vakalarda bugüne kadar en yaygın kullanılan test romatoid faktördür, RA'ya duyarlı olmasına rağmen özgül olmayan bir parametredir. Şüpheli vakalarda ya da düşük RF sevyeli vakalarda otoantikor ölçümü tanı koymada yardımcı olabilir. Anti RA-33 otoantikor ölçümü RA'l1 hastalarda kullanılan otoantikor testlerinden biridir. Bu çalışmanın amacı sağlıklı bireyler ile RA'lı bireylerin Anti-RA 33 seviyesini karşılaştırmak ve Anti-RA 33 seviyesinin RA tanısında önemini değerlendirmektir.

Yöntem: American College of Rheumatology (ACR) RA klasifikasyon kriterlerine göre belirlenmiş hastalık süresi en az iki yıl olan 28 i bayan,12 si erkek toplam 40 RA'li hasta ile aynı sayıda kontrol grubu sağlıklı kişiler çalışmaya alındı. 


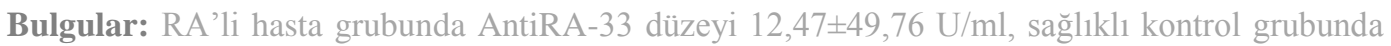
AntiRA-33 düzeyi 1,96 $\pm 1.82 \mathrm{U} / \mathrm{ml}$ olup gruplar arası istatiksel olarak bir fark bulunmadı.

Sonuç: RA'lı hastalarda AntiRA-33 düzeyi ile sağlıklı kontrol grubu arasında anlamlı bir fark bulunamadi.

Anahtar sözcükler: Romatoid Artrit, Romatoid Faktör, Anti-RA33

\section{INTRODUCTION}

Rheumatoid Arthritis (RA) is the most encountered autoimmune disorder affecting about $1 \%$ of the world population with no known etiology, proceeding with chronic inflammation, resulting in functional loss and mortality ${ }^{1}$. While its etiology is not exactly known, some risk factors such as genetic, hormonal and infectious agents have been investigated. There is a strong relationship between RA and HLA-DR4, and HLA class II DR1 tissue group ${ }^{2}$.

The early diagnosis of RA is of due importance for the prevention of the damage to the joint tissue by means of treatment $^{3}$. Laboratory tests are significant for the monitoring of RA activity and evaluation of the patients' responses to the treatment. For the cases with suspected RA, the most frequently used test for now is rheumatoid factor. Although it is sensitive to RA, it is not a specific parameter for $\mathrm{RA}^{4}$. Because it is seen together with many disorders and also identified even in healthy individuals, diagnostic value of this particular parameter is still a contentious point. The search for a more specific and sensitive parameter for the diagnosis of patients with has been focused on related autoantibodies ${ }^{5,6}$. The measurement of the other autoantibodies might prove to be helpful especially for the cases with low RF titer or with contentions diagnosis. The majority of the autoantibodies detected in RA are not specific for RA as they might also be detected in other disorders. This group includes rheumatoid factor, anti-RA33, anti-calpastatin, anti-nuclear antibody (ANA), anti-collagentype II, antifibronectin and anti-GPI antibodies. While the positivity rate of anti-RA33 for $\mathrm{RA}$ is \% 35, it might be positive in the early RA prior to the onset of symptoms of the disorder ${ }^{6-8}$.
Antigen RA 33 is a nuclear antigen specific for RA. For the recent years, some antibodies have been identified against the antigen RA 33, and these antibodies are classified under the label of anti-RA. The raw nuclear substance or recombined antigens of anti RA-33 can be easily identified by means of immunoblotting technique. While anti RA 33 is identified in almost $35 \%$ of the patients with RA, except for few cases, it has not been detected in other autoimmune or rheumatoid disorders. While anti-RA33 antibodies are detected in almost a third of the patients with RA, anti-RA33 is found to be positive for only $1 \%$ of the healthy individuals. The subsequent clinical studies conducted have come up with different and conflicting results ${ }^{9-11}$.

The present study was conducted to shed more light on the significance of antiRA33 for a more accurate RA diagnosis, as the studies in the related literature on the clinical importance of anti-RA33 for the early diagnosis of the RA cases is limited in number and these studies have conflicting results. The purpose of the present study is to compare the antiRA33 level of the patients with long term RA with anti-RA33 levels of healthy individuals, and clarify the clinical significance of this particular autoantibody.

\section{MATERIAL AND METHODS}

Total 40 patients (28 female and 12 male) identified with RA at least for the last five years according to the classification criteria of American College of Rheumatology (ACR) reviewed in 1987, which is also accepted as the diagnostic norms in the Rheumatology out-patient clinic under the Physiotherapy and Rehabilitation Service of Research Hospital, and 40 healthy controls 
included in the present study. Following the confirmation of the Ethical Council, prior to the beginning of the study, the participants were informed about the details of the study and their consents were obtained. The individuals who were included in the control group were recruited from the patients who applied to the Physiotherapy and Rehabilitation outpatient clinic and who were found to be healthy. The individual with a history of rheumatoid disorder both in their personal and family history were excluded from the study. Moreover, individuals with a malign disorder, any disorders of the collagen tissues other than RA, osteoarthritis of the hands, and the patients who were not willing to cooperate were also excluded from the study. Erythrocyte sedimentation rate (ESR), C-reactive protein (CRP), RF, AntiRA-33 levels were measured in both the patient and control groups. The length of the disease and disease activity score (DAS) 28 values were recorded for the patient group.

Following the one night fasting, the blood samples were taken for the laboratory studies from the participants through the antecubital vein into EDTA tubes for the measurement of the antiRA33 levels. Within one hour, plasma was separated after centrifugation for $10 \mathrm{~min}$ at $5000 \mathrm{x}$ g. Following the separation, by providing the required temperature conditions for the transportation $\left(2-8^{\circ} \mathrm{C}\right)$, it was transported to the laboratory conditions where the measurements would be conducted. The plasma samples were stored at $-20^{\circ} \mathrm{C}$ in the deep freeze for a 12-week period.

CRP and RF: Becman Coulter (USE) test kit and Becman Coulter image devices were used automatically by means of nefelometric method in the measurement of CRP and RF.

ESR: Becton Dicson test kit and BD Sedisystem (USE) devices were used automatically.

AntiRA-33: AESKULISA (Germany) test kit was employed on Triturus (Italy) device automatically by enzyme Immunoassey (EİA) method. In accordance with the Kit prospectus, $<12$ $\mathrm{U} / \mathrm{mL}$ was regarded as normal,12-18 $\mathrm{U} / \mathrm{mL}$ as suspected, and $>18 \mathrm{U} / \mathrm{mL}$ as positive.

\section{Statistical Analysis}

The data were presented mean \pm SD and percentages. In the analysis of the data, SPSS statistics 14,0 software was used. The comparison of statistical data of RA and control groups was done by test and the comparison of the ones about ratio was done by chi-square test. $\mathrm{P}<0,05$ was regarded as meaningful.

\section{RESULTS}

For the RA and control groups, there were no individuals excluded from the study; the research data were collected from all cases. For the RA group, there were 40 cases ( 28 female and 12 male) diagnosed with RA at least for the last five years. For the patients classified in the RA group, the average length of time

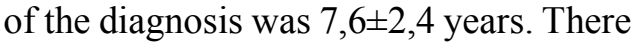
were 40 healthy individuals included in the control group. It was detected that disease modifying anti-rheumatic drugs (DMARD) were used in all cases with RA. Among the patients with RA, 23 was prescribed with methotrexate $(\% 51,7), 8$ with sulfasalazine (\%18), 7 with methotrexate+ anti-TNF (\%15.7), 2 with antimalarial drug (\%5). Only 16 patients (\%36) were prescribed with corticosteroid in combination with these medicines. The average daily doses of corticosteroids were between 5-20 $\mathrm{mg}$ /day levels. While there was a significant difference between RA patients and healthy controls in terms of their CRP, ESR, RF levels ( $p<0.05)$, there was no meaningful difference in terms of gender and age $(p>0.05)$. For the RA group, the positive level of RF was determined to be meaningfully higher in comparison to the one of the control group (\%20 for the controls and \%80 for the RA: $\mathrm{p}<0.05)$ (Table 1). 
Table 1. Characteristics of patients in RA and control groups

\begin{tabular}{|c|c|c|}
\hline & $\begin{array}{l}\text { RA group } \\
\quad(n=40)\end{array}$ & $\begin{array}{l}\text { Control group } \\
\qquad(\mathrm{n}=40)\end{array}$ \\
\hline Age & $48.7 \pm 1$ & $45.8 \pm 1$ \\
\hline Gender F/M & $28 / 12$ & $28 / 12$ \\
\hline ESR & $37,9 \pm 63,7^{a}$ & $14,5 \pm 12,3$ \\
\hline CRP & $13.5 \pm 13,6^{\mathrm{b}}$ & $3.79 \pm 3.2$ \\
\hline RF positive & $32(\% 80)^{\mathrm{c}}$ & $8(\% 20)$ \\
\hline DAS 28 score & $2.3 \pm 0.8$ & \\
\hline \multicolumn{3}{|c|}{$\begin{array}{l}\text { a,b,c } \mathrm{p}<0,05 \text { in comparison to the controls. } \\
\text { a,b,c Different letters of superscript mean significant difference }(\mathrm{p}<0.05) \text {. } \\
\text { Data were presented as mean } \pm \text { SD or } \mathrm{n}(\%) \text {. } \\
\text { RA: Rheumatoid arthritis: ESR: Erythrocyte sedimentation rate: CRP:C-reactive } \\
\text { protein DAS: Disease Activity Score }\end{array}$} \\
\hline
\end{tabular}

Table 2. Serum antiRA-33 values of the RA and control groups.

\begin{tabular}{|l|c|c|c|}
\hline Groups & $\begin{array}{c}\text { AntiRA-33 } \\
\text { (below 12U/mL) }\end{array}$ & $\begin{array}{c}\text { AntiRA-33 } \\
\text { (above 18U/mL) }\end{array}$ & Total \\
\hline RA group, \% & $37(\% 92,5)$ & $3(\% 7.5)$ & $40(\% 100)$ \\
\hline Control group, \% & $40(\% 100)$ & 0 & $40(\% 100)$ \\
\hline Total Number,\% & $77(\% 96,3)$ & $3(\% 3,8)$ & $80(\% 100)$ \\
\hline
\end{tabular}

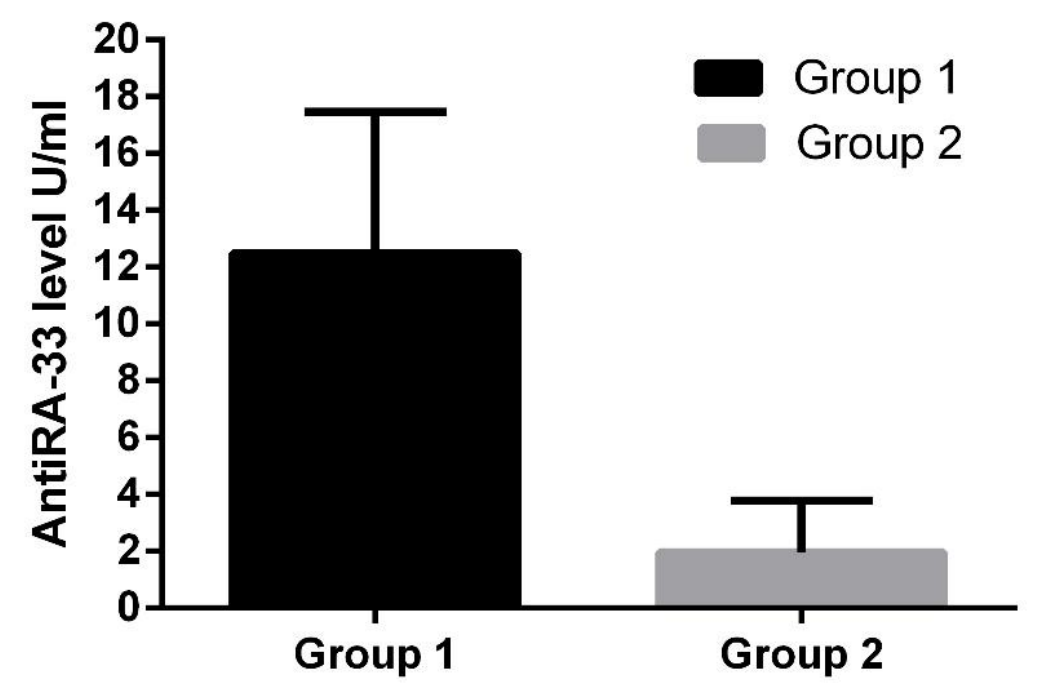

Figure1. The comparison of serum Anti-RA 33 levels 
When serum AntiRA-33 levels of both groups were compared, serum AntiRA33 levels of Group 1 was determined as $12,47 \pm 4,97 \mathrm{U} / \mathrm{mL}$, and that of Group 2 as $1,96 \pm 1.82$, which means that there was no meaningful difference between the groups ( $>0.05$ ). When serum AntiRA33 levels were determined as negative below $12 \mathrm{U} / \mathrm{mL}$ and positive above 18 $\mathrm{U} / \mathrm{mL}$, and evaluated in accordance with these values, the difference between RA and control groups was found to be insignificant $(p>0.05)$. While for only three patients $(\% 7,5)$ in RA group serum AntiRA-33 levels were found to be above $18 \mathrm{U} / \mathrm{mL}$, for the remaining $37(\% 92,5)$ patients, serum AntiRA-33 levels were found to be below $12 \mathrm{U} / \mathrm{mL}$. The average DAS score for the three patients in RA group with AntiRA-33 levels above 18 $\mathrm{U} / \mathrm{mL}$ was $3,6 \pm 0.7 \mathrm{U} / \mathrm{mL}$.Among the healthy controls, there were no individual with AntiRA-33above $18 \mathrm{U} / \mathrm{mL}$; in other words,antiRA-33 levels of the all cases in the control group were determined below $12 \mathrm{U} / \mathrm{mL}$

\section{DISCUSSION}

In the present study, which investigated the serumanti-RA33 levels of the RA cases, it was concluded that the determination of anti-RA33 levels does not have any clinical contribution to the findings supporting RA diagnosis. This conclusion is conflictive with the findings of the previous studies in the related literature emphasizing the significance of anti-RA33 in the diagnosis of RA. In the present study, while serum anti-RA33 level was high in $7,5 \%$ of the RA cases, this ratio in the literature ranges from $30 \%$ to $35 \%$.For the recruitment procedure of the cases, by including the cases who were diagnosed with RA for at least five years and receiving treatment for RA,the effect of antiRA-33 on RA diagnosis was aimed to be determined; however, such antiRA-33 levels reaching levels close to the ones in the literature were not determined. Moreover, the fact that three cases with high DAS scores also had high antiRA33 levels is likely to be clinically significant.

$\mathrm{RF}$ is the most commonly employed test for the cases with suspected RA.
Although RF is a sensitive parameter for RA, it is not specific for RA [13,14]. While, in various studies with RA, RF was found to be in positive titer as high as $50 \%-80 \%$, it was also determined that healthy individuals might have positive RF titer by about $5 \%$. Moreover, this rate might rise to $15 \%$ with age. In addition to this, RF might be determined as positive in systemic lupus erythematosus (SLE) scleroderma, sjogren syndrome, psoriaticarthritis, gut, viral infections, and malign disorders. The fact that RF might be positive in healthy individuals and that it might be in high levels in other rheumatoid disorders have led to the search for new autoantibodies. As a result, in recent years, there has been an increase in the search for possible tests, which might give new insights about the early diagnosis and prognosis of $\mathrm{RA}^{12-16}$.

Anti-RA33 was the first identified autoantibody in distinguishing early phases of RA from other forms of arthritis and rheumatoid disorders. In the initial studies on anti-RA33, it was assumed that this antibody was better than RF in differential diagnosis ${ }^{17}$. In a study conducted by Hueberet al. ${ }^{18} 67$ RA patients and 180 patients diagnosed with other rheumatoid disorders were investigated. Whileanti-RA33 antibody was determined positive in 21 RA cases (31\%), anti-RA33 antibody was detected in only four cases out of 180 control cases. Cordonnier et al. ${ }^{19}$, in 1996, in a study conducted to determine serological profile of early RA, and to find out whetheranti-RA33 antibody and antinuclear antibody (ANA) contributed to the diagnosis, the autoantibody sensitivity in early RA cases was found to be $40,8 \%$ for RF and $28,6 \%$ for antiRA33. Moreover, it was also determined that while the positive RA diagnosis maintained through the follow-up of the patients, RF titer turned out to be negative for the $58 \%$ of early RA patients receiving treatment over time. In the same study, in nearly $50 \%$ of RF negative patients, anti-RA33 was found to be positive.

Nell et al. ${ }^{20}$, in a retrospective study, investigated RF, anti-cyclic citrullinated peptide antibodies (anti-CCP) and anti- 
RA33 antibodies on 200 patients with early inflammatory joint disease. Among the patients, 102 developed RA and 98 developed other inflammatory joint diseases. For the patients with RF values above $50 \mathrm{U} / \mathrm{mL}$ and over, it was noted that anti- CCP and anti-RA33 antibodies did not have any contribution to the diagnosis. For the patients with RF values above $50 \mathrm{U} / \mathrm{mL}$ and over, $\mathrm{RF}$ and anti-CCP exhibited a similar sensitivity and marked specificity for RA. It was suggested that for the early inflammatory joint disease, gradual antibody detection is a sensitive and efficient method in the detection of RA patients with poor prognosis. For this reason, the investigation should start with detection of RF; and for the patients with RF $50 \mathrm{U} / \mathrm{mL}$ and below, the measurement of anti-CCP antibody and subsequently, the measurement of anti- RA33 antibody were recommended. However, the RA patient group of the present study was limited in number and the fact that in the long term, anti-RA33 positive was not monitored for the patients with RF and Anti-CCP negative is one of the limitations of the present study.

Zhou et al. ${ }^{21}$, in a study conducted on 88 RA cases, argued that anti-RA33 is not an RA specific autoantibody, and that the combination of anti-RA33 positive and anti-RA36 positive might prove contributive in the diagnosis of the RA cases. Tomoumet al. ${ }^{22}$, in a study conducted on 34 juvenile idiopathic arthritis patients, found that anti- RA33 antibody revealed positive results by $66,7 \%$. It is the only study that found the highest anti-RA33 antibody positive on the patients with arthritis. The same study also found a relation between anti- RA33 antibody and disease activity and bone resorption.

In recent years, with the increase in the number of studies conducted on antiCCP antibody and the inclusion of antiCCP antibodies in the new ACR diagnostic criteria, Anti- RA33 antibodies have ceased to be significant for the diagnosis early of RA patients ${ }^{23-}$ 26. Both its low sensitivity and its unavailability in routine laboratories have contributed to anti-RA33 antibodies' loss of significance for the early diagnosis of RA case. Nevertheless, the measurement of anti-RA33 antibodies might be a wiser way of reaching to a diagnosis for patients with early arthritis, RF titer50U/mL and below and with negative anti-CCP antibody. Although the selection of RA cases was made among the individuals receiving RA treatment for a long period of time, it was thought that on condition that RA diagnosis was supported with the measurement of other new autoantibodies, the evaluation of the clinical activity of anti-RA33 level would be more appropriate. Moreover, in research with a higher number of RA cases, the determination of its diagnostic value by means of measuring anti-RA33 level might shed more light on routine clinical applications.

The fact that the present study did not have a higher number of patients constitutes a limitation.

In conclusion, according to the findings of the present study, the measurement of anti-RA33 levels for RA patients does not have any clinical significance for the diagnosis. In the suspected rheumatoid arthritis cases with negative RF and Anti$\mathrm{CCP}$, further clinical studies are needed for the evaluation of diagnostic value and strength of the measurement of antiRA33 autoantibodies.

\section{REFERENCES}

1. Maini RN, Zvaifler NJ: Rheumatoid arthritis and spondyloarthropathy. Klippel JH, Dieppe PA (ed). Rheumatology. St Louis: Mosby, 1994; 3: 1-4.

2. Bottini N, Firestein GS. Epigenetics in rheumatoid arthritis: a primer for rheumatologists. Curr Rheumatol Rep. 2013; 15: 372.

3. Gramling A, O'Dell JR. Initial management of rheumatoid arthritis. Rheum Dis Clin North Am. 2012; 38: 311-25.

4. Renaudineau Y, Jamin C, Saraux A, Youinou P. Rheumatoid factor on a daily basis. Autoimmunity 2005; 38 : 11-6. 
5. Schoels M, Bombardier C, Aletaha D. Diagnostic and prognostic value of antibodies and soluble biomarkers in undifferentiated peripheral inflammatory arthritis: a systematic review. J Rheumatol Suppl 2011; 87: 20-5.

6. Keser G. Romatoid artritte laboratuar testleri. Türkiye Klinikleri J Int Med Sci 2006; 6: 314.

7. Schellekens GA, de Jong BA, van den Hoogen FH, van de Putte LB, van venrooij WJ: Citrulline is an essential constituent of antigenic determinants recognized by rheumatoid arthritis-specific autoantibodies. J Clin İnvest 1998; 101: 273-81.

8. Firestein GS: Etiology and pathogenesis of rheumatoid arthritis. Harris ED, Budd CR Firestein GS (ed), Kelley's Textbook of Rheumatology. Seventh (7th) edition Philadelphia, 2005: 9961042.

9. Aho K, Steiner G, Kurki P, Paimela L, Leirisalo-Repo M, Palosuo T,et al.Anti-RA 33 as a marker antibody of rheumatoid arthritis in a Finnish population. Clin Exp Rheumatol. 1993; 11: 645-7.

10. Meyer O, Tauxe F, Fabregas D, Gabay C, Goycochea M, Haim T, et al. Anti-RA 33 antinuclear autoantibody in rheumatoid arthritis and mixed connective tissue disease: comparison with antikeratin and antiperinuclear antibodies. Clin Exp Rheumatol. 1993; 11: 473-8.

11. Van Boekel M, Vossenaar, ER, van den Hoogen, FHJ, van Venrooij WJ. Autoantibody systems in rheumatoid arthritis: specificity, sensitivity and diagnostic value. Arthritis Research 2001; 4: 87-93.

12. Levin RW, Park J, Ostrov B, Reginato A, Baker DG, Bomalaski $\mathrm{JS}$, et al. A cross-sectional and longitudinal comparison of the Rome criteria for active rheumatoid arthritis (equivalent to the American College of Rheumatology 1958 criteria) and the American College of Rheumatology 1987 criteria for rheumatoid arthritis. Arthritis Rheum. 1994; 37: 1479-86.

13. Schellekens GA, Visser H, de Jong BAW, van den Hoogen FH, Hazes JM, Breedeveld FC, van Venrooij WJ. The diagnostic properties of rheumatoid arthritis antibodies recognizing anti-cyclic citrulinated peptide. Arthritis Rheum, 2000; 43: 155-63.

14. S. Rantapää-Dahlqvist, B.A.W. de Jong, E. Berglin Hallmans G, Wadell G, Stenlund H, Sundin U, van Venrooij WJ. Antibodies against cyclic citrullinated peptide and $\operatorname{IgA}$ rheumatoid factor predict the development of rheumatoid arthritis. Arthritis Rheum. 2003; 48: 2741-9.

15. Westwood OM, Nelson PN, Hay FC. Rheumatoid factors: what's new? Rheumatology 2006; 45: 37985.

16. Khurana R, Berney SM. Clinical aspects of rheumatoid arthritis. Pathophysiology 2005; 12: 153-65.

17. Gabay C, Prieur AM, Meyer O. Occurrence of antiperinuclear, antikeratin, and anti-RA 33 antibodies in juvenile chronic arthritis. Ann Rheum Dis 1993; 52): 785-9.

18. Hueber W, Hassfeld W, Smolen JS, Steiner G. Sensitivity and specificity of anti-Sa autoantibodies for rheumatoid arthritis. Rheumatology (Oxford). 1999; 38: 155-9.

19. Cordonnier C, Meyer O, Palazzo E, de Bandt M, Elias A, Nicaise P, et al. Diagnostic value of anti-RA33 antibody, antikeratin antibody, antiperinuclear factor and antinuclear antibody in early rheumatoid arthritis: comparison with rheumatoid factor. $\mathrm{Br} \mathrm{J}$ Rheumatol 1996; 35: 620-4.

20. Nell VP, Machold KP, Stamm TA, Eberl G, Heinzl H, Uffmann M, et al. Autoantibody profiling as early diagnostic and prognostic tool for rheumatoid arthritis. Ann Rheum Dis. 2005; 64: 1731-6. 
21. Zhou ZJ, Jiang M, Song QF. Evaluation of anti-rheumatoid arthritis $36 \mathrm{kD}$ and anti-33 kD antibodies in the diagnosis of rheumatoid arthritis. Zhonghua Nei Ke Za Zhi. 1994; 33: 251-4.

22. Tomoum HY, Mostafa GA, El Shahat EM. Autoantibody to heterogeneous nuclear ribonucleoprotein-A2 (RA33) in juvenile idiopathic arthritis: clinical significanc. Pediatr Int 2009; 51: 188-92.

23. Luban S, Li ZG.Citrullinated peptide and its relevance to rheumatoid arthritis: an update.Int $\mathbf{J}$ Rheum Dis 2010; 13: 284-7.

24. Pincus T, Sokka T. Laboratory tests to assess patients with rheumatoid arthritis: advantages and limitations. Rheum Dis Clin North Am 2009; 35: 731-4.

25. Zintzaras E, Papathanasiou AA, Ziogas DC, Voulgarelis M.The reporting quality of studies investigating the diagnostic accuracy of anti-CCP antibody in rheumatoid arthritis and its impact on diagnostic estimates. BMC Musculoskelet Disord 2012; 13: 113.

26. Kay J, Upchurch KS. ACR/EULAR 2010 rheumatoid arthritis classification criteria. Rheumatology (Oxford). 2012; 51: 5-9. 